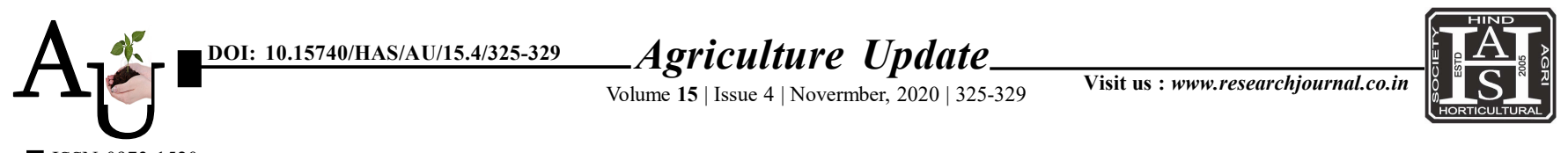

ISSN-0973-1520

\title{
Research Article: A comparative gender study on participation and time utilization in community works in YSR Kadapa district of Andhra Pradesh
}

P. Laxmi Prasanna and B. P. Mohapatra

Article Chronicle :

Received :

12.08.2020;

Revised:

26.09.2020;

Accepted :

15.10.2020

KEY WoRds :

Farmer, Farm women, Community works,

Time utilization,

Participation
SUMMARY : The present study attempts to compare the participation and time utility pattern of farmer and farm women in community works. The investigation was conducted in YSR Kadapa district of Andhra Pradesh. Total 120 respondents selected from 10 randomly selected villages, out of 120 respondents 60 respondents were farmers, 60 respondents were farmwomen. Farmer and farm women were interviewed separately with pre structured interview schedule. Majority of farm women were middle aged, illiterates, landless labour, working as agriculture labour, falling under medium income level. Most of farmers were actively participated social rituals (93.3) and allotted more time to organizing village welfare activities (1.66) social awareness programmes and field trips and exhibitions. Farm women actively participated to SHG meetings (1.5). Farm women allotted very less time to field trips and exhibitions (0.3). The study has recommended need to empower and educate the farm women to participate in community management programmes by imparting knowledge.

How to cite this article : Prasanna, P. Laxmi and Mohapatra, B.P. (2020). A comparative gender study on participation and time utilization in community works in YSR Kadapa district of Andhra Pradesh. Agric. Update, 15(4): 325-329; DOI : 10.15740/HAS/AU/15.4/325-329. Copyright@ 2020: Hind Agri-Horticultural Society.

Author for correspondence :

\section{P. Laxmi Prasanna} Department of Agriculture Extension, Agriculture College,

Bapatla (A.P.) India

Email: prasannachandu 539@gmail.com

See end of the article for authors' affiliations 